\title{
Investigation of the T4 and T6 Heat Treatment Cycles of Semi-Solid Processed Aluminium Alloy A356
}

\author{
H. Möller ${ }^{*}$, , G. Govender ${ }^{1}$ and W.E. Stumpf ${ }^{2}$ \\ ${ }^{I}$ Materials Science and Manufacturing, CSIR, Pretoria, 0001, South Africa \\ ${ }^{2}$ Materials Science and Metallurgical Engineering, University of Pretoria, South Africa
}

\begin{abstract}
The heat treatment cycles that are currently applied to semi-solid processed components are mostly those that are in use for dendritic casting alloys. These heat treatments are not necessarily the optimum treatments. It is shown that a decrease of the solution treatment time at $540^{\circ} \mathrm{C}$ from 6 hours to 1 hour does not alter the $\mathrm{T} 4$ or $\mathrm{T} 6$ tensile properties of the SSM processed A356 alloy. Slightly better impact properties are obtained with the shorter solution treatment. This could lead to time and energy savings. Natural aging prior to artificial aging causes the time-to-peak-hardness to be longer compared to the time when only artificial aging is used. Quenching after solution treatment in water at $70^{\circ} \mathrm{C}$ results in slightly lower tensile properties than after quenching in water at $25^{\circ} \mathrm{C}$. The magnesium content of alloy A356 has a significant influence on the T4 and T6 properties of the alloy.
\end{abstract}

\section{INTRODUCTION}

Semi-solid metal (SSM) processing is a unique manufacturing method to produce near-net shape products for various industrial applications [1]. With this method, a globular microstructure is obtained in contrast with conventional liquid casting, where a dendritic microstructure is attained.

Two different SSM processes exist, namely thixocasting and rheocasting. With thixocasting, a specially prepared billet of solid material with a globular microstructure is reheated into the semi-solid range and formed. Rheocasting involves preparation of a SSM slurry directly from the liquid, followed by a forming process such as high pressure die casting (HPDC). The increased costs associated with thixocasting have resulted in rheocasting becoming the preferred semi-solid process [2].

A356 is a conventional aluminium casting alloy which is used in many applications due to its high strength-to-weight ratio. This alloy is also probably the most popular alloy used for semi-solid metal forming. This is due to its high fluidity and good "castability" [3]. These castings are generally heat treated to obtain the desired combination of strength and ductility. However, the heat treatment cycles that are currently applied to semi-solid processed components are mainly those that are in use for dendritic casting alloys. These heat treatments are not necessarily the optimum treatments, as the difference in solidification history and microstructure of rheocast components should be considered [4]. It is known that alloy A356 responds to natural aging after the solution treatment and quench. The precipitation hardening that result from natural aging alone produces the useful T4 temper. The T6 heat treatment produces maximum strength in aluminium alloys. Unfortunately, the cost and production time associated with this treatment is substantial. Shortening the T6 heat treatment cycle would therefore have major implications on manufacturing cost and productivity [5].

\footnotetext{
*Address correspondence to this author at the Materials Science and Manufacturing, CSIR, Pretoria, 0001, South Africa; Tel: +27 (12) 841 2139; Fax: +27(12) 841 3378; E-mail: hmoller@csir.co.za
}

In previous work by the authors [6], it was shown by means of aging curves that the optimum solution treatment time at $540^{\circ} \mathrm{C}$ is 1 hour. This represented the shortest possible solution treatment time to obtain complete dissolution of strengthening alloying elements, while still retaining a relatively fine microstructure. It was also shown that SSM HPDC A356 hardened significantly at room temperature after solution treatment. The time required to obtain maximum hardness at artificial aging temperatures of 160 to $190^{\circ} \mathrm{C}$ could be estimated using Arrhenius-type equations. Finally, it was concluded that the artificial aging response of the alloy could be increased by an instant transfer from quench to artificial aging.

The objective of this study was to characterise the $\mathrm{T} 4$ and T6 heat treatment cycles of rheocast alloy A356 by means of tensile and impact testing. As in the previous work, the influence of solution treatment time, natural aging time and artificial aging parameters were investigated. In addition, the effects of water quench temperature on the T4 and T6 tensile properties were also studied. Lastly, the influence of $\mathrm{Mg}$ fluctuations from $0.25 \mathrm{wt} \%$ to $0.45 \mathrm{wt} \%$ (the lower and upper limits of the specification, see Table 1) was also considered.

Table 1. Chemical Composition Limits (wt\%) for Alloy A356 [7] and the Compositions Used in this Study

\begin{tabular}{|c|c|c|c|c|c|c|}
\hline & Si & Mg & Fe & Ti & Other (Each) & Other (Tot) \\
\hline \hline Min & 6.5 & 0.25 & - & - & - & - \\
\hline Max & 7.5 & 0.45 & 0.20 & 0.20 & 0.05 & 0.15 \\
\hline \multicolumn{7}{|c|}{ Tensile and Impact } \\
\hline \multirow{7}{*}{} & Si & Mg & Fe & Ti & Sr \\
\cline { 2 - 7 } & 7.1 & 0.25 & 0.14 & 0.08 & 0.03 \\
\cline { 2 - 7 } & 7.1 & 0.31 & 0.13 & 0.09 & 0.02 \\
\cline { 2 - 7 } & 6.9 & 0.45 & 0.12 & 0.09 & 0.02 \\
\hline \multicolumn{7}{|c|}{ Quench } \\
\hline & 7.1 & 0.36 & 0.10 & 0.07 & 0.02 \\
\cline { 2 - 6 } & 7.2 & 0.40 & 0.10 & 0.08 & 0.02 \\
\hline
\end{tabular}




\section{EXPERIMENTAL}

Semi-solid metal slurries of A356 containing different magnesium contents (chemical composition given in Table 1) were prepared using the CSIR (Council for Scientific and Industrial Research) rheocasting process [8]. It is known that silicon has the strongest influence on the ratio of solid to liquid fraction of all alloying elements in A356 (much stronger than magnesium). A fluctuation of $1 \mathrm{wt} \%$ silicon in aluminium (as is allowed according to Table 1) results in a solid fraction change of almost $9 \%$ if the casting temperature is held constant [9]. For this reason, it was attempted to keep the silicon contents fairly constant, while only varying the wt $\% \mathrm{Mg}$. It can also be seen from Table $\mathbf{1}$ that strontium was added in all cases. The size and shape of the silicon particles are modified with additions of strontium. It is known that modified alloys undergo fast spheroidisation, while complete spheroidisation is not achieved in unmodified alloys, even after long solution treatment times. Therefore, shorter solution heat treatments can be employed with modified castings [10].

Plates $(4 \mathrm{~mm} \times 80 \mathrm{~mm} \times 100 \mathrm{~mm})$ were cast in steel moulds with a 50 ton high pressure die casting (HPDC) machine. Solution heat treatments were performed at $540^{\circ} \mathrm{C}$ for either 1 hour or 6 hours, followed by a water quench $\left(25^{\circ} \mathrm{C}\right.$ or $70^{\circ} \mathrm{C}$ ). The samples were then naturally aged (NA) for various times before being artificially aged to determine artificial aging curves.

To study the T4 temper, samples were naturally aged for at least 120 hours after solution treatment and quench. Vickers hardness (VHN) was determined $(20 \mathrm{~kg}$ load) from the average of at least four readings per sample. The average hardness values were found to be reproducible within \pm 3 VHN for all heat treatment conditions tested. All samples used for microscopy were etched in $0.5 \% \mathrm{HF}$ solution.

The tensile properties of samples in the T4 and T6 temper were determined using a total of 5 tensile tests for each heat treatment condition. The tensile samples (sub-standard size) were machined from the plates (see Fig. (1) for the dimensions of the samples).

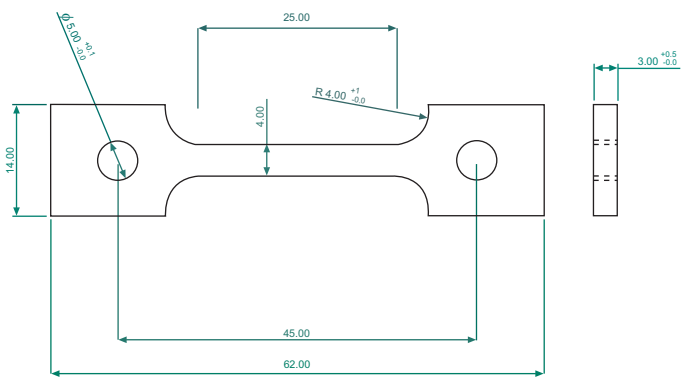

Fig. (1). The dimensions of the samples (in millimeters) used for tensile testing.

The impact strengths were determined using a Zwick impact tester with a $40 \mathrm{kpcm}$ hammer. Five non-standard size samples $\left(55 \mathrm{~mm} \times 10 \mathrm{~mm} \times 3 \mathrm{~mm}\right.$ with a $45^{\circ} \mathrm{V}$-notch of $2 \mathrm{~mm}$ depth) were used for each heat treatment condition.

\section{RESULTS AND DISCUSSION}

Fig. (2) shows a typical optical micrograph of the A356 after SSM HPDC. It is seen that the material has a globular primary grain structure and a fine eutectic.

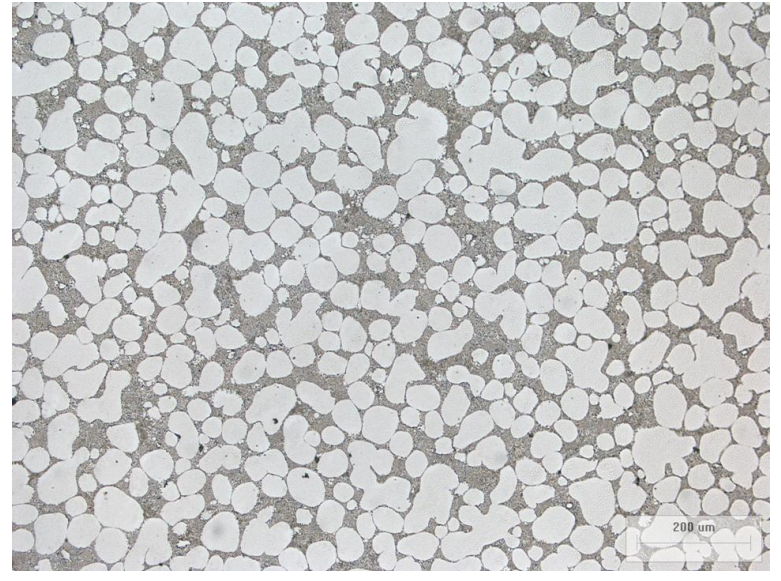

Fig. (2). Typical optical micrograph of SSM HPDC alloy A356 (with $0.31 \% \mathrm{Mg}$ )

\section{SOLUTION TREATMENT AT $540^{\circ} \mathrm{C}$}

Figs. $(3,4)$ show typical optical micrographs of alloy A356 after solution treatment at $540^{\circ} \mathrm{C}$ for 1 hour and 6 hours respectively. Solution treatment resulted in the eutectic structure changing to a globular type structure. It is seen that the silicon particles of the eutectic are much coarser after a solution treatment for 6 hours than after 1 hour, and that the silicon interparticle spacing is increased by the longer solution treatment.

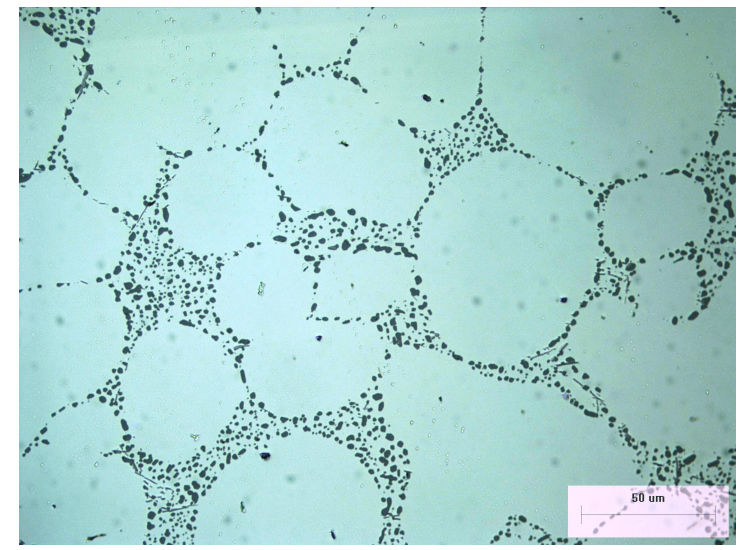

Fig. (3). Optical micrograph of alloy A356 (0.31\% Mg) after solution treatment at $540^{\circ} \mathrm{C}$ for 1 hour.

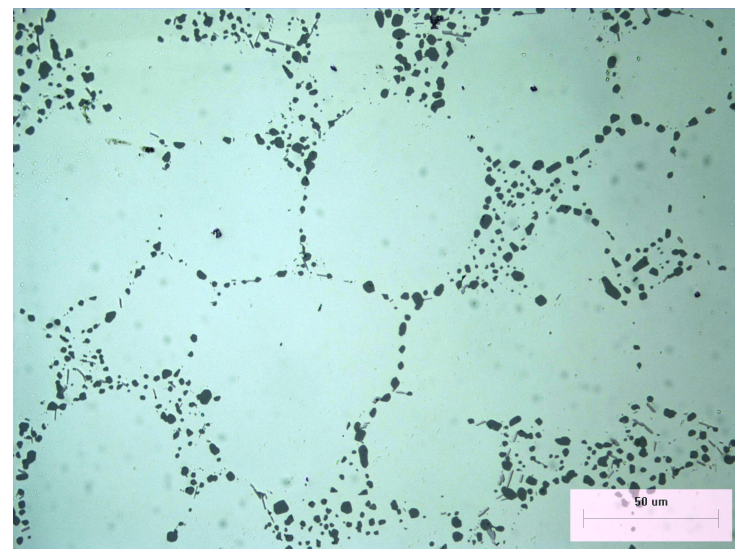

Fig. (4). Optical micrograph of alloy A356 $(0.31 \% \mathrm{Mg})$ after solution treatment at $540^{\circ} \mathrm{C}$ for 6 hours. 


\section{NATURAL AGING AND A356-T4}

\section{Influence of Mg-Content}

Fig. (5) shows natural aging curves for SSM HPDC alloy A356 after solution treatment at $540^{\circ} \mathrm{C}$ for 1 hour, followed by a water quench. The material is soft immediately after quenching ( $\mathrm{VHN}=\sim 53$ ), but thereafter the hardness increases rapidly. The hardness eventually levels out after about 120 hours - the T4 temper. The magnesium content (between the lower and upper limits of 0.25 to $0.45 \mathrm{wt} \%$ Table 1) has a significant effect on the natural aging behaviour of alloy A356. The reason for this can best be understood by considering the decomposition of the supersaturated solid solution (SSS) [11]:

$\mathrm{SSS} \rightarrow(\mathrm{Mg}+\mathrm{Si})_{\text {clusters }} / \mathrm{GP}(\mathrm{I})_{\text {spherical }}$

$\rightarrow \beta^{\prime \prime} / \mathrm{GP}(\mathrm{II})_{\text {needles }} \rightarrow \beta^{\prime}$ rods $+\mathrm{Si}+$ others

$\rightarrow \beta_{\text {plates }}+\mathrm{Si}$

where $\quad \mathrm{GP}=$ Guinier-Preston zones

$$
\beta=\text { equilibrium } \mathrm{Mg}_{2} \mathrm{Si}
$$

$\beta^{\prime}$ and $\beta^{\prime \prime}=$ metastable precursors of $\beta$

The natural aging response of alloy A356 is considered to be due to $(\mathrm{Mg}+\mathrm{Si})$ clusters and $\mathrm{GP}$ zones. A higher $\% \mathrm{Mg}$ should lead to a higher volume fraction of these clusters and GP-zones, resulting in improved hardness and strength.

\section{Tensile and Impact Properties of A356-T4}

The tensile and impact properties of SSM HPDC A356T4 are shown in Table 2.

Similar tensile properties are obtained when the material was solution treated for 1 hour or 6 hours at $540^{\circ} \mathrm{C}$. This implies that energy and time savings can be achieved by using the shorter solution treatment of only 1 hour. The tensile properties presented in Table 2 , as well as some of the tensile properties presented later in Table $\mathbf{3}$, were used to show that linear relationships are obtained between $\mathrm{wt} \% \mathrm{Mg}$ and the yield strength (YS) and ultimate tensile strength (UTS) of A356-T4 (Figs. 6,7).

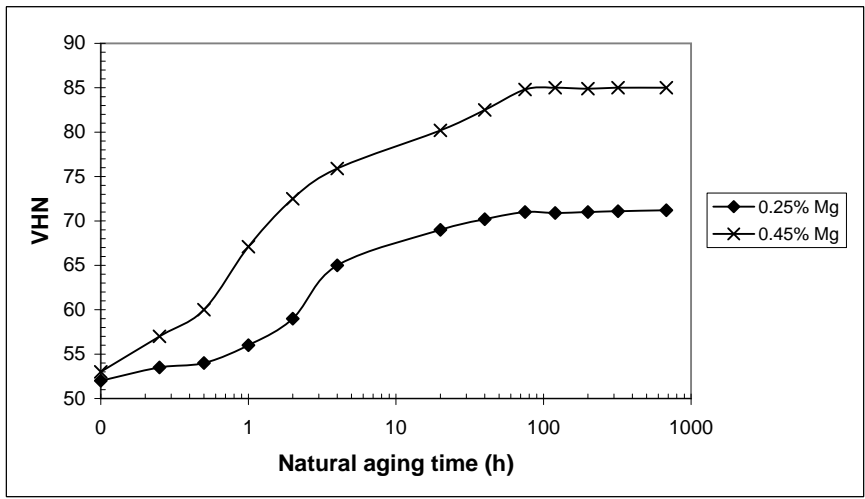

Fig. (5). Natural aging curves for SSM HPDC A356 following solution treatment at $540^{\circ} \mathrm{C}$ for $1 \mathrm{~h}$ and a water quench.

Slightly higher impact properties are obtained after a solution treatment of $1 \mathrm{~h}$ rather than $6 \mathrm{~h}$ for each composition (Table 2). This is in contradiction to what was found by Zhang et al. [12] for permanent mould cast A356-T6. They found that shorter solution treatments than the standard 6 hours resulted in lower impact strengths. This was attributed to the smaller interparticle Si-spacing after shorter solution treatments, which assisted with crack growth. However, Ogris [13] showed that the impact strength for thixoformed A356-T6 was better using only 3 minutes solution treatment compared to 12 hours. This was attributed to the fact that the $\mathrm{Si}$ was three dimensionally separated after 3 minutes at $540^{\circ} \mathrm{C}$, whereas longer times caused the silicon to agglomerate and form large interconnected silicon crystals.

Table 2. Yield Strength (YS), Ultimate Tensile Strength (UTS), \% Elongation and Impact Strength of T4 Heat Treated Samples. The Standard Deviation from five Values for Tensile and Impact Properties is Also Indicated in Brackets

\begin{tabular}{|c|c|c|c|c|}
\hline Heat Treatment & $\begin{array}{c}\text { YS } \\
\text { (MPa) }\end{array}$ & $\begin{array}{l}\text { UTS } \\
\text { (MPa) }\end{array}$ & \% Elong & $\begin{array}{c}\text { Impact } \\
\text { Strength }\left(\mathrm{kJ} / \mathrm{m}^{2}\right)\end{array}$ \\
\hline \multicolumn{5}{|c|}{$0.25 \% \mathrm{Mg}$} \\
\hline $540^{\circ} \mathrm{C}, 1 \mathrm{~h}$ & $\begin{array}{c}137 \\
(4.2)\end{array}$ & $\begin{array}{c}252 \\
(6.2)\end{array}$ & $\begin{array}{c}20.2 \\
(0.94)\end{array}$ & $\begin{array}{l}110.0 \\
(3.7)\end{array}$ \\
\hline $540^{\circ} \mathrm{C}, 6 \mathrm{~h}$ & $\begin{array}{l}133 \\
(2.9)\end{array}$ & $\begin{array}{l}244 \\
(3.5)\end{array}$ & $\begin{array}{l}17.2 \\
(2.5)\end{array}$ & $\begin{array}{c}106.9 \\
(9.1)\end{array}$ \\
\hline \multicolumn{5}{|c|}{$0.31 \% \mathrm{Mg}$} \\
\hline $540^{\circ} \mathrm{C}, 1 \mathrm{~h}$ & $\begin{array}{c}146 \\
(7.3)\end{array}$ & $\begin{array}{c}263 \\
(8.8)\end{array}$ & $\begin{array}{l}17.4 \\
(1.8)\end{array}$ & $\begin{array}{c}103.0 \\
(5.5)\end{array}$ \\
\hline $540^{\circ} \mathrm{C}, 6 \mathrm{~h}$ & $\begin{array}{c}148 \\
(4.2)\end{array}$ & $\begin{array}{l}263 \\
(6.0)\end{array}$ & $\begin{array}{l}16.9 \\
(2.3)\end{array}$ & $\begin{array}{l}97.6 \\
(6.0)\end{array}$ \\
\hline \multicolumn{5}{|c|}{$0.45 \% \mathrm{Mg}$} \\
\hline $540^{\circ} \mathrm{C}, 1 \mathrm{~h}$ & $\begin{array}{c}163 \\
(1.5)\end{array}$ & $\begin{array}{r}284 \\
(2.6)\end{array}$ & $\begin{array}{l}16.5 \\
(1.9)\end{array}$ & $\begin{array}{l}87.3 \\
(6.4)\end{array}$ \\
\hline $540^{\circ} \mathrm{C}, 6 \mathrm{~h}$ & $\begin{array}{c}167 \\
(1.7)\end{array}$ & $\begin{array}{l}286 \\
(2.8)\end{array}$ & $\begin{array}{l}17.7 \\
(1.7)\end{array}$ & $\begin{array}{l}77.1 \\
(4.7)\end{array}$ \\
\hline
\end{tabular}

Table 3. YS, UTS, \% Elongation of T4 Heat Treated Samples (0.40 wt\% Mg-A356). The Standard Deviation from Five Values for Tensile Properties is Also Indicated in Brackets

\begin{tabular}{|c|c|c|c|}
\hline Heat Treatment & $\begin{array}{c}\text { YS } \\
\text { (MPa) }\end{array}$ & $\begin{array}{c}\text { UTS } \\
\text { (MPa) }\end{array}$ & $\begin{array}{c}\text { \% } \\
\text { Elong }\end{array}$ \\
\hline \hline $540^{\circ} \mathrm{C}-1 \mathrm{~h}, 25 \mathrm{WQ}$ & $\begin{array}{c}152 \\
(3.5)\end{array}$ & $\begin{array}{c}282 \\
(6.1)\end{array}$ & $\begin{array}{c}15.8 \\
(3.3)\end{array}$ \\
\hline $540^{\circ} \mathrm{C}-1 \mathrm{~h}, 70 \mathrm{WQ}$ & $\begin{array}{c}138 \\
(2.2)\end{array}$ & $\begin{array}{c}264 \\
(6.5)\end{array}$ & $\begin{array}{c}16.5 \\
(2.5)\end{array}$ \\
\hline
\end{tabular}

The $\mathrm{wt} \% \mathrm{Mg}$ of alloy A356 seems to play a more important role than solution treatment time on the impact strength in the T4 temper, with high Mg-content resulting in lower impact strengths (Table 2). Linear relationships are found between impact strength and wt $\% \mathrm{Mg}$ (Fig. 8).

\section{A356-T4 as a Function of Water Quench Temperature}

The results presented in Table 2 were obtained by water quenching (WQ) the A356 after solution treatment in water at room temperature $\left(25^{\circ} \mathrm{C}\right)$. However, higher quench temperatures $\left(65-100^{\circ} \mathrm{C}\right)$ are frequently used for $\mathrm{A} 356$ castings 
to minimise distortion [10]. Less supersaturation of solutes should be obtained with a high temperature quench and the resultant $\mathrm{T} 4$ properties are expected to be slightly decreased [10]. To characterise this phenomenon, A356 samples were quenched in water at 25 and $70^{\circ} \mathrm{C}$ after the solution treatment. As expected, quenching at $70^{\circ} \mathrm{C}$ after solution treatment results in lower peak hardness (Fig. 9) and tensile properties than quenching in water at $25^{\circ} \mathrm{C}$ (Table 3, Fig. 10).

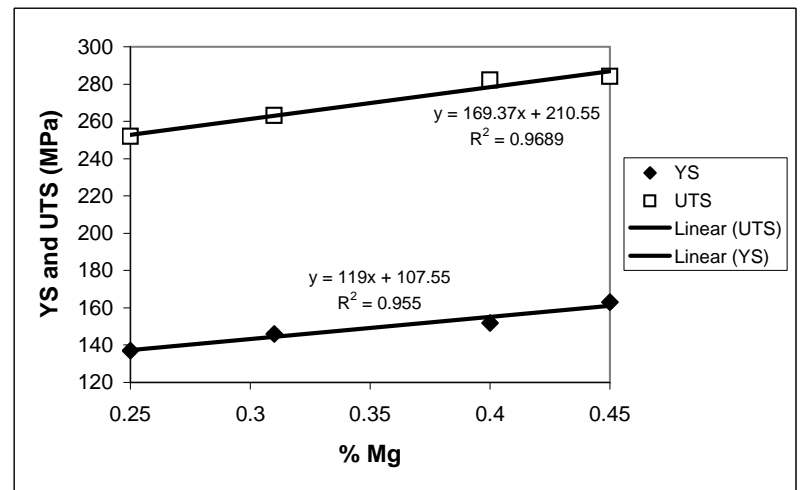

Fig. (6). Yield strength and UTS of alloy A356 as a function of the Mg-content (wt\%) of the alloy for the "540-1" T4 heat treatment

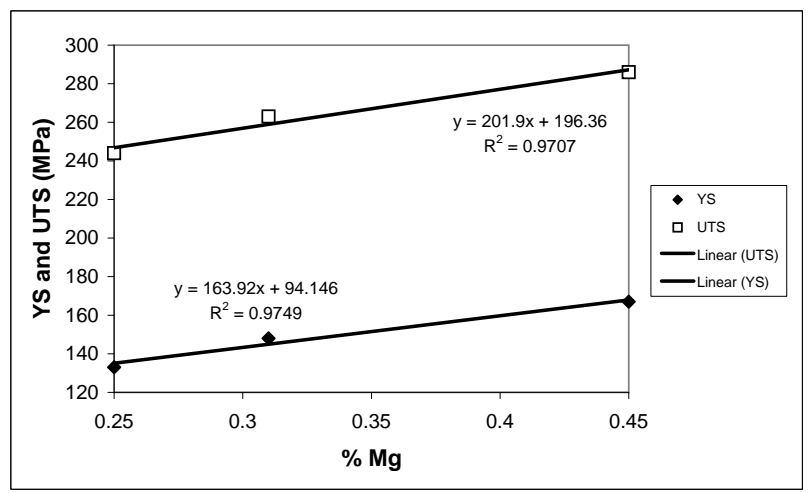

Fig. (7). Yield strength and UTS of alloy A356 as a function of the Mg-content (wt\%) of the alloy for the " $540-6$ " T4 heat treatment.

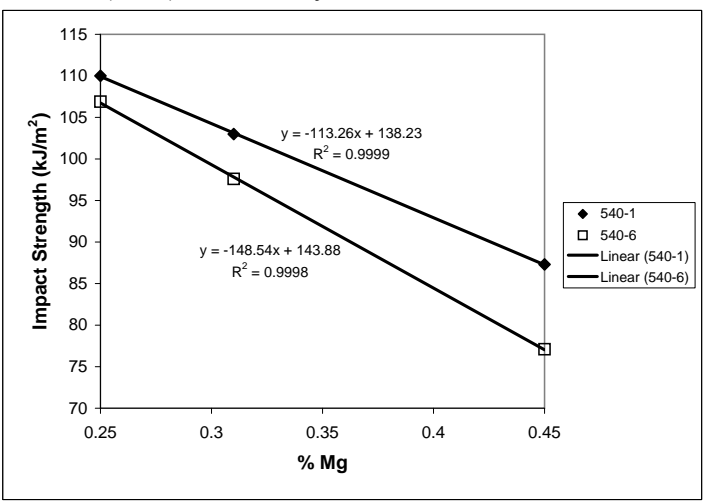

Fig. (8). Impact strength as a function of Mg-content of alloy A356T4.

\section{ARTIFICIAL AGING AND A356-T6}

\section{Influence of Mg-Content and Prior Natural Aging}

The significant influence that the magnesium-content of alloy A356 also has on the artificial aging response is shown in Fig. (11) (no prior natural aging) and Fig. (12) (with $120 \mathrm{~h}$ prior natural aging). Peak hardening with artificial aging (i.e. from the T6 temper) results from the precipitation of the metastable and coherent $\beta^{\prime \prime}[11]$. In this case, a higher $\% \mathrm{Mg}$ should, firstly, lead to a higher volume fraction of the second phase $\beta$, and most likely also of $\beta^{\prime}$ and $\beta^{\prime \prime}$ but, secondly, may even alter the thermodynamic and compositional characteristics of the precipitates by increasing the driving force for nucleation and thus providing a differently sized distribution.

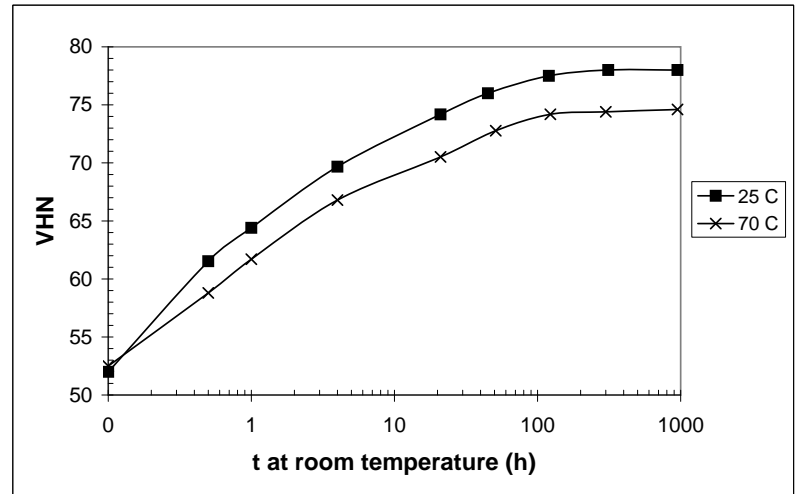

Fig. (9). Natural aging curves for $0.36 \mathrm{wt} \% \mathrm{Mg}-\mathrm{A} 356$ solution treated at $540^{\circ} \mathrm{C}$ for $1 \mathrm{~h}$, followed by water quenching at 25 and $70^{\circ} \mathrm{C}$.

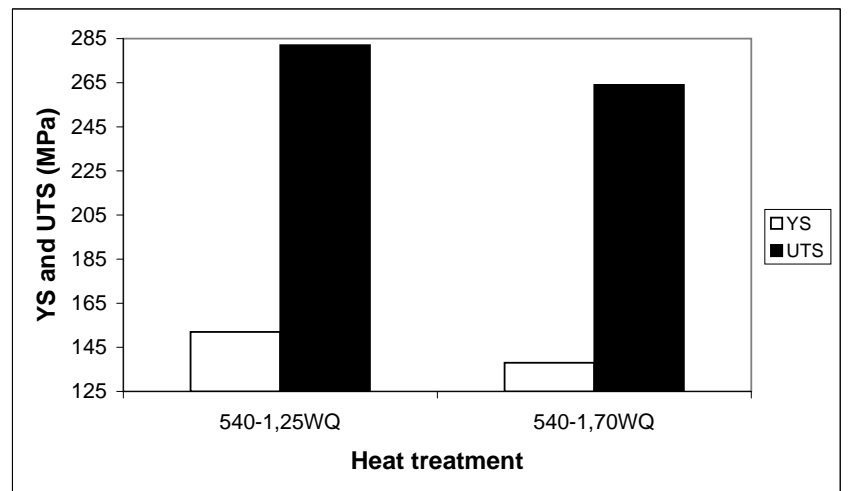

Fig. (10). A356-T4 tensile properties as a function of water quench temperature $(0.40 \% \mathrm{Mg})$.

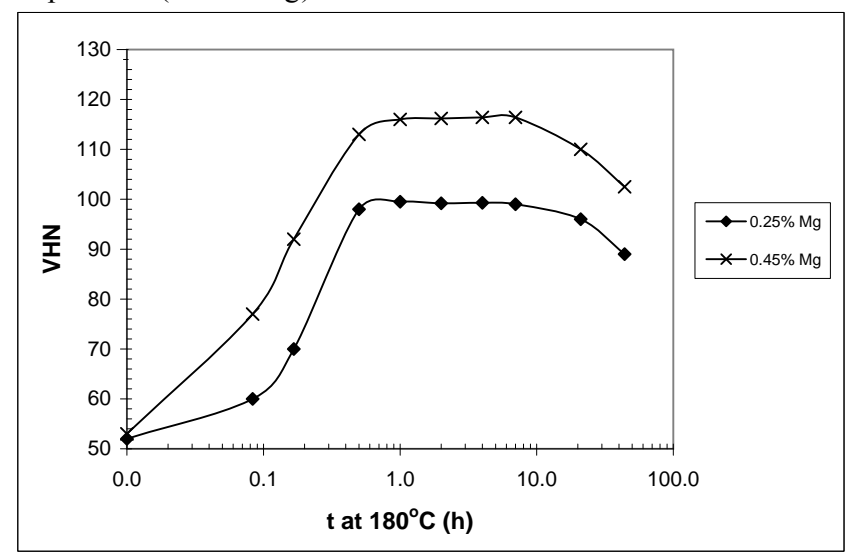

Fig. (11). Artificial aging curves at $180^{\circ} \mathrm{C}$ for alloy $\mathrm{A} 356$ (after $0 \mathrm{~h}$ natural aging time).

The influence of natural aging on the subsequent artificial aging response has been studied before by the authors [6]. It was concluded that reversion of the solute clusters is responsible for the sluggish artificial aging response and initial softening in naturally aged alloy A356. It can be seen from Fig. (11) that maximum hardness is reached as a hardness plateau within 1 hour at $180^{\circ} \mathrm{C}$ (with no prior natural aging). If natural aging precedes artificial aging (even as 
short as 1 hour, as shown by the authors [6]), a hardness peak is reached after 4 hours at $180^{\circ} \mathrm{C}$ (Fig. 12).

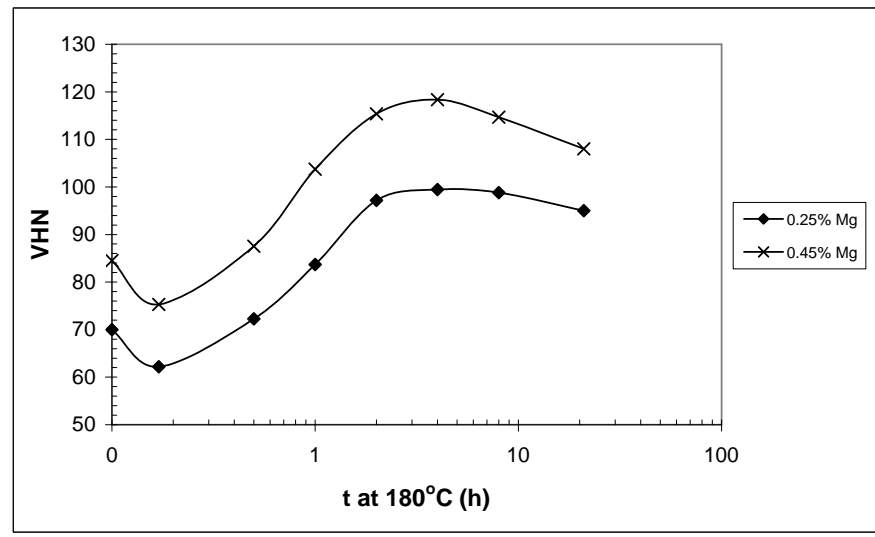

Fig. (12). Artificial aging curves at $180^{\circ} \mathrm{C}$ for alloy A356 (after 120 $\mathrm{h}$ natural aging time).

\section{Tensile and Impact Properties of A356-T6}

The tensile and impact properties of SSM HPDC A356T6 are shown in Table 4.

Table 4. YS, UTS, \% Elongation and Impact Strength of T6 Heat Treated Samples. The Standard Deviation from five Values for Tensile and Impact Properties is Also Indicated in Brackets

\begin{tabular}{|c|c|c|c|c|}
\hline Heat Treatment & $\begin{array}{l}\text { YS } \\
\text { (MPa) }\end{array}$ & $\begin{array}{l}\text { UTS } \\
\text { (MPa) }\end{array}$ & $\begin{array}{c}\% \\
\text { Elong }\end{array}$ & $\begin{array}{c}\text { Impact } \\
\text { Strength }\left(\mathbf{k J} / \mathbf{m}^{2}\right)\end{array}$ \\
\hline \multicolumn{5}{|c|}{$0.25 \% \mathrm{Mg}$} \\
\hline $\begin{array}{c}540^{\circ} \mathrm{C}-6 \mathrm{~h}, 0 \mathrm{~h} \text { NA, } \\
180^{\circ} \mathrm{C}-1 \mathrm{~h}\end{array}$ & $\begin{array}{c}238 \\
(1.5)\end{array}$ & $\begin{array}{l}293 \\
(6.6)\end{array}$ & $\begin{array}{l}7.2 \\
(2.5)\end{array}$ & $56.5(6.7)$ \\
\hline $\begin{array}{c}540^{\circ} \mathrm{C}-1 \mathrm{~h}, 0 \mathrm{~h} \text { NA, } \\
180^{\circ} \mathrm{C}-1 \mathrm{~h}\end{array}$ & $\begin{array}{l}235 \\
(4.6)\end{array}$ & $\begin{array}{c}303 \\
(5.3)\end{array}$ & $\begin{array}{c}9.7 \\
(1.5)\end{array}$ & $57.0(2.4)$ \\
\hline $\begin{array}{c}540^{\circ} \mathrm{C}-6 \mathrm{~h}, 20 \mathrm{~h} \text { NA, } \\
180^{\circ} \mathrm{C}-4 \mathrm{~h}\end{array}$ & $\begin{array}{c}236 \\
(6.8)\end{array}$ & $\begin{array}{l}295 \\
(3.7)\end{array}$ & $\begin{array}{c}8.3 \\
(1.4)\end{array}$ & $56.1(4.1)$ \\
\hline $\begin{array}{c}540^{\circ} \mathrm{C}-1 \mathrm{~h}, 20 \mathrm{~h} \text { NA, } \\
180^{\circ} \mathrm{C}-4 \mathrm{~h}\end{array}$ & $\begin{array}{l}243 \\
(1.4)\end{array}$ & $\begin{array}{l}303 \\
(1.5)\end{array}$ & $\begin{array}{l}7.9 \\
(0.7)\end{array}$ & $58.3(1.6)$ \\
\hline \multicolumn{5}{|c|}{$0.31 \% \mathrm{Mg}$} \\
\hline $\begin{array}{c}540^{\circ} \mathrm{C}-6 \mathrm{~h}, 0 \mathrm{~h} \text { NA } \\
180^{\circ} \mathrm{C}-1 \mathrm{~h}\end{array}$ & $\begin{array}{l}248 \\
(4.5)\end{array}$ & $\begin{array}{l}315 \\
(5.9)\end{array}$ & $\begin{array}{c}9.3 \\
(2.1)\end{array}$ & $50.6(2.3)$ \\
\hline $\begin{array}{c}540^{\circ} \mathrm{C}-1 \mathrm{~h}, 0 \mathrm{~h} \text { NA } \\
180^{\circ} \mathrm{C}-1 \mathrm{~h}\end{array}$ & $\begin{array}{l}247 \\
(3.2)\end{array}$ & $\begin{array}{l}319 \\
(0.6)\end{array}$ & $\begin{array}{c}9.2 \\
(0.9)\end{array}$ & $54.1(3.0)$ \\
\hline $\begin{array}{c}540^{\circ} \mathrm{C}-6 \mathrm{~h}, 20 \mathrm{~h} \text { NA, } \\
180^{\circ} \mathrm{C}-4 \mathrm{~h}\end{array}$ & $\begin{array}{l}255 \\
(2.4)\end{array}$ & $\begin{array}{l}317 \\
(3.8)\end{array}$ & $\begin{array}{c}9.3 \\
(1.4)\end{array}$ & $49.1(6.7)$ \\
\hline $\begin{array}{c}540^{\circ} \mathrm{C}-1 \mathrm{~h}, 20 \mathrm{~h} \text { NA, } \\
180^{\circ} \mathrm{C}-4 \mathrm{~h}\end{array}$ & $\begin{array}{c}254 \\
(6.1)\end{array}$ & $\begin{array}{l}313 \\
(7.3)\end{array}$ & $\begin{array}{l}10.5 \\
(0.9)\end{array}$ & $50.9(4.3)$ \\
\hline \multicolumn{5}{|c|}{$0.45 \% \mathrm{Mg}$} \\
\hline $\begin{array}{c}540^{\circ} \mathrm{C}-6 \mathrm{~h}, 0 \mathrm{~h} \text { NA } \\
180^{\circ} \mathrm{C}-1 \mathrm{~h}\end{array}$ & $\begin{array}{l}275 \\
(4.2)\end{array}$ & $\begin{array}{l}340 \\
(2.2)\end{array}$ & $\begin{array}{c}9.7 \\
(1.1)\end{array}$ & $38.3(3.8)$ \\
\hline $\begin{array}{c}540^{\circ} \mathrm{C}-1 \mathrm{~h}, 0 \mathrm{~h} \text { NA, } \\
180^{\circ} \mathrm{C}-1 \mathrm{~h}\end{array}$ & $\begin{array}{c}277 \\
(4.2)\end{array}$ & $\begin{array}{l}342 \\
(1.1)\end{array}$ & $\begin{array}{c}8.9 \\
(0.3)\end{array}$ & $43.0(0.7)$ \\
\hline $\begin{array}{c}540^{\circ} \mathrm{C}-6 \mathrm{~h}, 20 \mathrm{~h} \text { NA, } \\
180^{\circ} \mathrm{C}-4 \mathrm{~h}\end{array}$ & $\begin{array}{l}293 \\
(3.2)\end{array}$ & $\begin{array}{l}346 \\
(1.4)\end{array}$ & $\begin{array}{c}8.9 \\
(0.8)\end{array}$ & $33.4(2.6)$ \\
\hline $\begin{array}{c}540^{\circ} \mathrm{C}-1 \mathrm{~h}, 20 \mathrm{~h} \text { NA, } \\
180^{\circ} \mathrm{C}-4 \mathrm{~h}\end{array}$ & $\begin{array}{c}292 \\
(6.2)\end{array}$ & $\begin{array}{l}341 \\
(3.6)\end{array}$ & $\begin{array}{c}7.8 \\
(1.2)\end{array}$ & $34.6(2.0)$ \\
\hline
\end{tabular}

It is seen that solution treatments of 1 hour or 6 hours at $540^{\circ} \mathrm{C}$ once more gave similar tensile results. The yield strength of samples that were naturally aged for 20 hours before artificial aging seems to be higher than for the samples that were not naturally aged, especially for the $0.45 \mathrm{wt} \%$ Mg samples (Fig. 13). It has been shown by the authors [14] in subsequent work that maximum yield strength in the T6 condition (within the hardness plateau) can be achieved after 2 hours at $180^{\circ} \mathrm{C}$ with no prior natural aging.

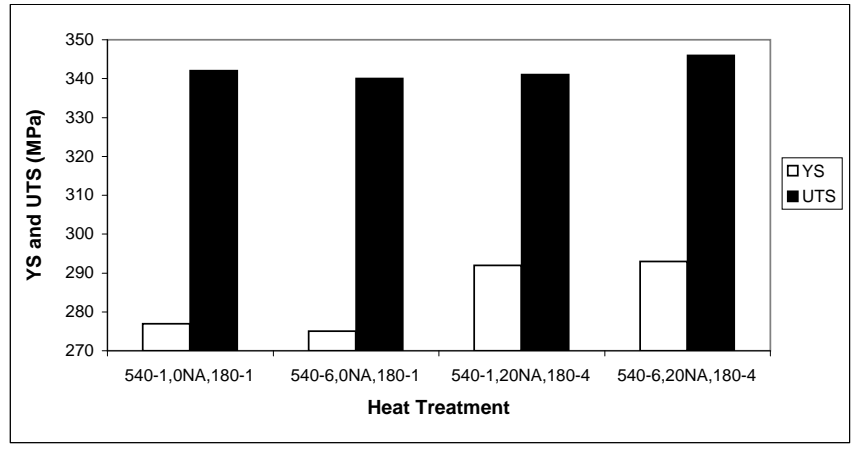

Fig. (13). Yield strength (YS) and ultimate tensile strength (UTS) of alloy A356 $(0.45 \% \mathrm{Mg})$ as a function of heat treatment conditions.

The tensile properties shown in Table 4, together with properties obtained by the authors in other work [14-16], were combined to determine the influence of Mg-content on the tensile properties of alloy A356-T6 (see Figs. 14,15). It can be seen that linear relationships also exist between YS, UTS and $\% \mathrm{Mg}$ for the different heat treatments.

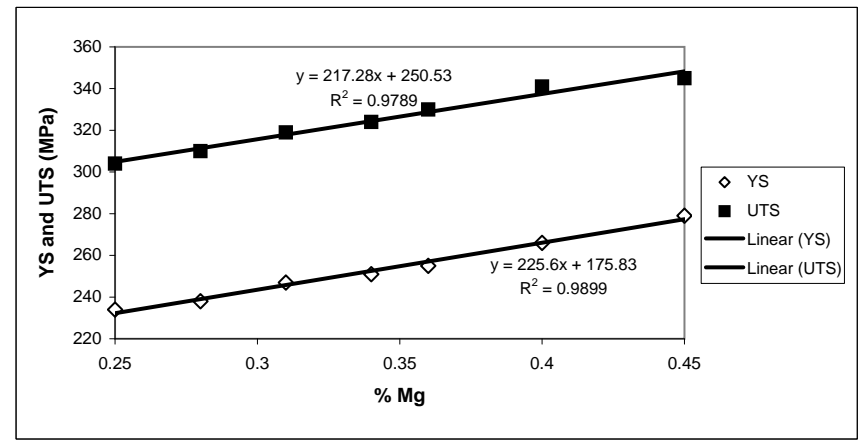

Fig. (14). YS and UTS of rheocast A356-T6 as a function of the $\mathrm{wt} \% \mathrm{Mg}$ of the alloy. Heat treatment: Solution treated at $540^{\circ} \mathrm{C}$ for 1 hour, water quenched $\left(25^{\circ} \mathrm{C}\right)$, no natural aging, artificial aging at $180^{\circ} \mathrm{C}$ for 1 hour.

The impact strength of rheocast A356-T6 is much lower than A356-T4 (Tables 2 and 4). Again, the shorter solution treatment of 1 hour resulted in slightly higher impact strengths in the T6 temper (Table 4). The Mg-content of the alloy has a greater effect on the T6 impact strength than the duration of the solution treatment (Figs. 16,17).

\section{A356-T6 as a Function of Water Quench Temperature}

The results presented thus far for A356-T6 were obtained by quenching the $\mathrm{A} 356$ after solution treatment in water at room temperature $\left(25^{\circ} \mathrm{C}\right)$. The influence of a higher tempera- 
ture quench of $70^{\circ} \mathrm{C}$ on the $\mathrm{T} 6$ properties was also investigated (Table 5).

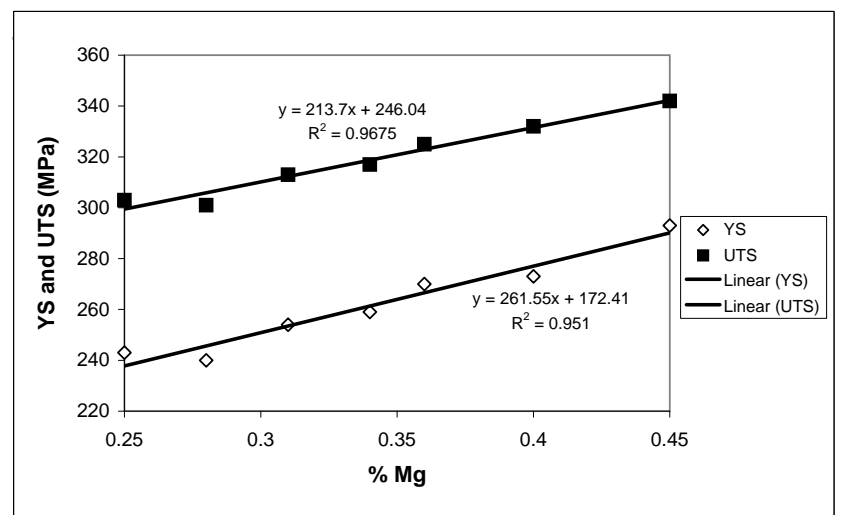

Fig. (15). YS and UTS of rheocast A356-T6 as a function of the $\mathrm{wt} \% \mathrm{Mg}$ of the alloy. Heat treatment: Solution treated at $540^{\circ} \mathrm{C}$ for 1 hour, water quenched $\left(25^{\circ} \mathrm{C}\right)$, natural aging for 20 hours, artificial aging at $180^{\circ} \mathrm{C}$ for 4 hours.

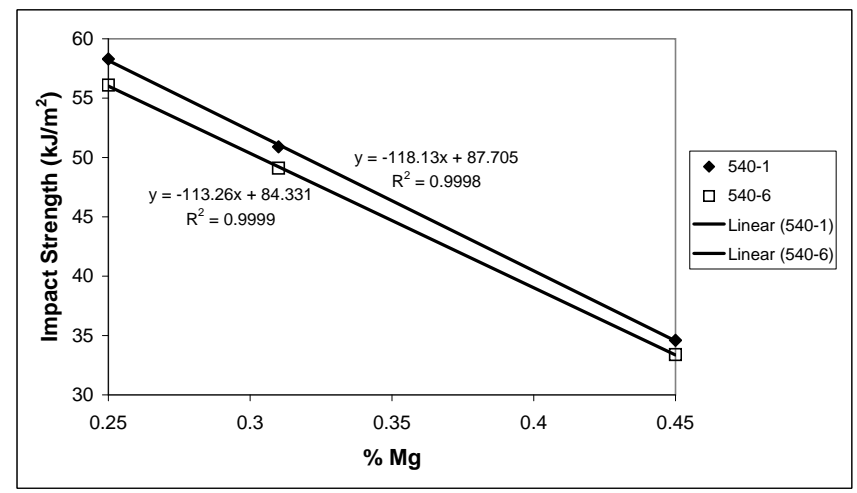

Fig. (16). Impact strength as a function of Mg-content of alloy A356-T6 (540-x,20NA,180-4).

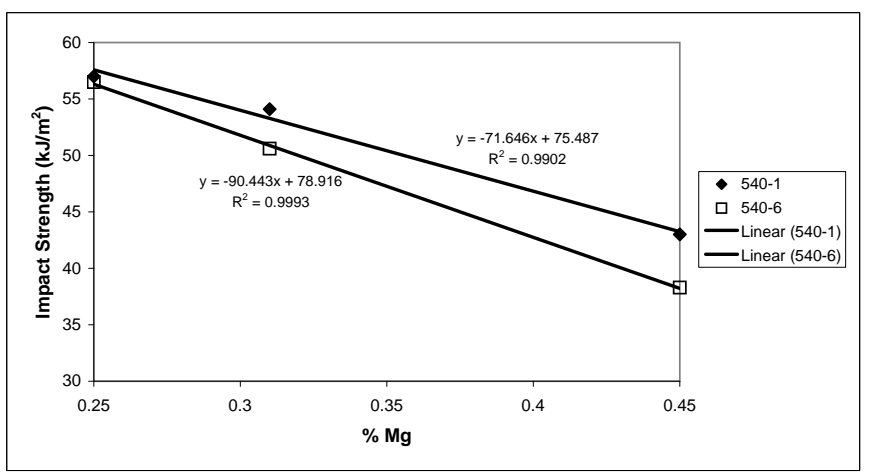

Fig. (17). Impact strength as a function of $\mathrm{Mg}$-content of alloy A356-T6 (540-x,0NA, 180-1).

From Fig. (18) it is seen that the higher quench temperature leads to a more sluggish artificial aging response (presumably due to less quenched in vacancies). The peak hardness is reached after about 4 hours. This peak hardness is slightly less than when a $25^{\circ} \mathrm{C}$ water quench is used. This might be due to a lower degree of supersaturation obtained after the $70^{\circ} \mathrm{C}$ water quench. The tensile properties of samples quenched in $70^{\circ} \mathrm{C}$ water and artificially aged at $180^{\circ} \mathrm{C}$ for 1 or 4 hours are highlighted in Figs. (19-21). The tensile properties after 4 hours at $180^{\circ} \mathrm{C}$ are better than those after only $1 \mathrm{~h}$ at $180^{\circ} \mathrm{C}$ (Fig. 21), in agreement with the aging curves (Fig. 18).

Table 5. YS, UTS, \% Elongation of T6 Heat Treated Samples (0.40wt\% Mg-A356). The Standard Deviation from Five Values for Tensile Properties is Also Indicated in Brackets

\begin{tabular}{|c|c|c|c|}
\hline Heat Treatment & YS (MPa) & UTS (MPa) & \% Elong \\
\hline \hline 540-1, 25WQ, 0NA, 180-1 & $266(7.5)$ & $341(9.5)$ & $7.8(1.8)$ \\
\hline 540-1, 25WQ, 0NA, 180-4 & $276(8.0)$ & $342(4.9)$ & $9.1(1.2)$ \\
\hline 540-1, 25WQ, 120NA, 180-4 & $280(5.2)$ & $337(6.0)$ & $6.9(1.8)$ \\
\hline 540-1, 70WQ, 0NA, 180-1 & $256(6.0)$ & $327(6.7)$ & $7.8(0.8)$ \\
\hline 540-1, 70WQ, 0NA, 180-4 & $265(5.0)$ & $330(2.7)$ & $9.8(2.1)$ \\
\hline 540-1, 70WQ, 120NA, 180-4 & $265(3.5)$ & $327(4.5)$ & $8.6(0.7)$ \\
\hline
\end{tabular}

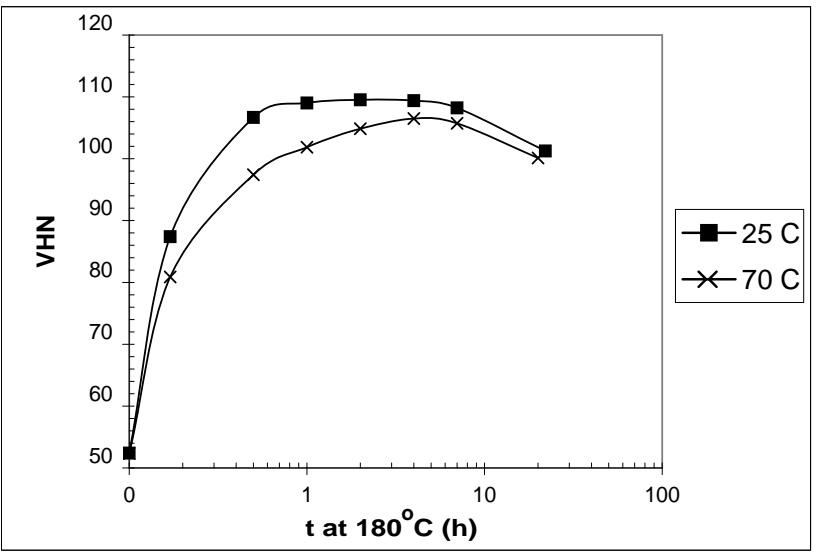

Fig. (18). Artificial aging curves at $180^{\circ} \mathrm{C}$ - water quench temperatures of 25 and $70^{\circ} \mathrm{C}$ were used and no natural aging prior to artificial aging $(0.36 \% \mathrm{Mg})$.

Artificial aging curves were also determined for A356 samples that were quenched in water at either 25 or $70^{\circ} \mathrm{C}$ after solution treatment at $540^{\circ} \mathrm{C}$ for $1 \mathrm{~h}$. In this case, the samples were naturally aged for $120 \mathrm{~h}$ before being artificially aged at $180^{\circ} \mathrm{C}$ (Fig. 22). As before, lower VHN values are obtained for the samples that were hot water quenched. Also, as expected, lower tensile properties are obtained (Fig. 23).

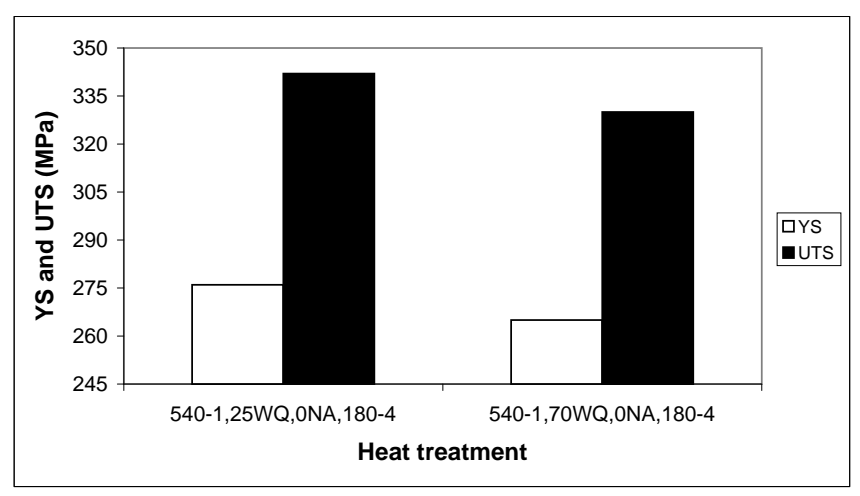

Fig. (19). Influence of water quench temperature on tensile properties. No natural aging prior to artificial aging at $180^{\circ} \mathrm{C}$ for $4 \mathrm{~h}$ $(0.40 \% \mathrm{Mg})$. 


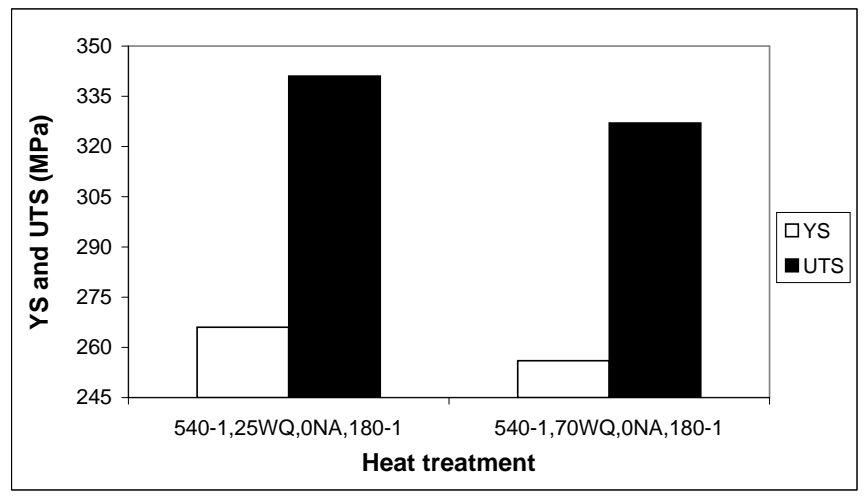

Fig. (20). Influence of water quench temperature on tensile properties. No natural aging prior to artificial aging at $180^{\circ} \mathrm{C}$ for $1 \mathrm{~h}$ $(0.40 \% \mathrm{Mg})$.

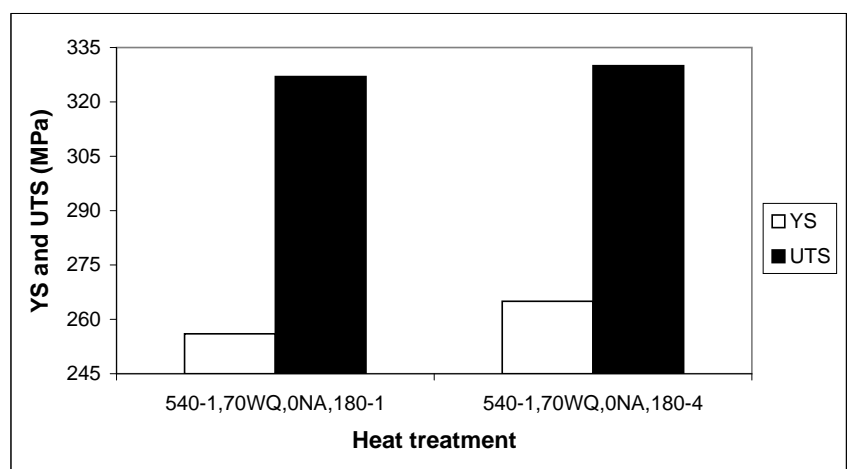

Fig. (21). Influence of artificial aging time on tensile properties of samples quenched in $70^{\circ} \mathrm{C}$ water. No natural aging prior to artificial aging at $180^{\circ} \mathrm{C}(0.40 \% \mathrm{Mg})$.

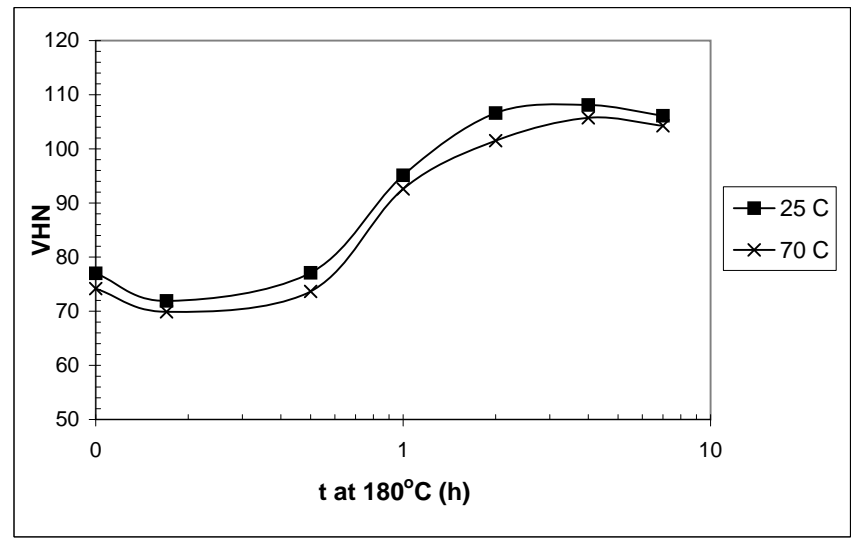

Fig. (22). Artificial aging curves at $180^{\circ} \mathrm{C}$ - water quench temperatures of 25 and $70^{\circ} \mathrm{C}$ were used and $120 \mathrm{~h}$ natural aging prior to artificial aging $(0.36 \% \mathrm{Mg})$.

The effects of natural aging can largely be removed in samples that were quenched in $70^{\circ} \mathrm{C}$ water by a $180^{\circ} \mathrm{C}, 4$ hour artificial aging treatment (Fig. 24). A similar result was obtained by the authors for samples that were quenched in $25^{\circ} \mathrm{C}$ water [14].

\section{CONCLUSIONS}

The conclusions of this study are:

- The magnesium content of alloy A356 has a significant influence on the natural and artificial aging behaviour of the alloy.

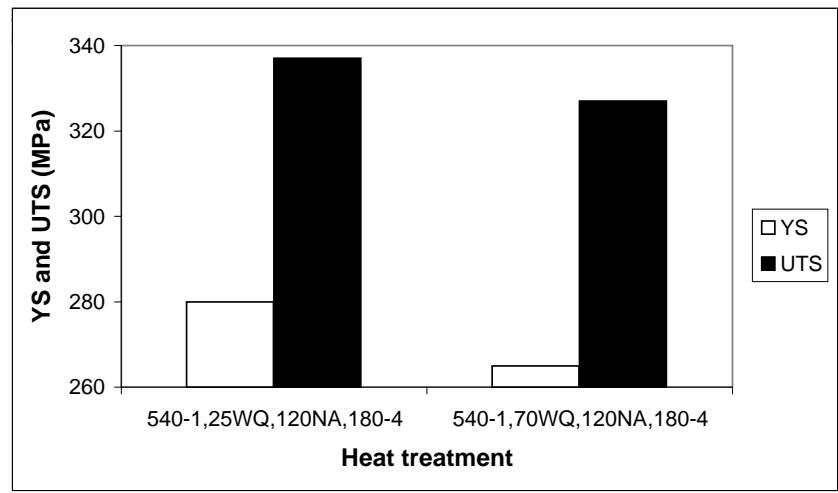

Fig. (23). Influence of water quench temperature on tensile properties. $120 \mathrm{~h}$ natural aging prior to artificial aging at $180^{\circ} \mathrm{C}$ for $4 \mathrm{~h}$ $(0.40 \% \mathrm{Mg})$.

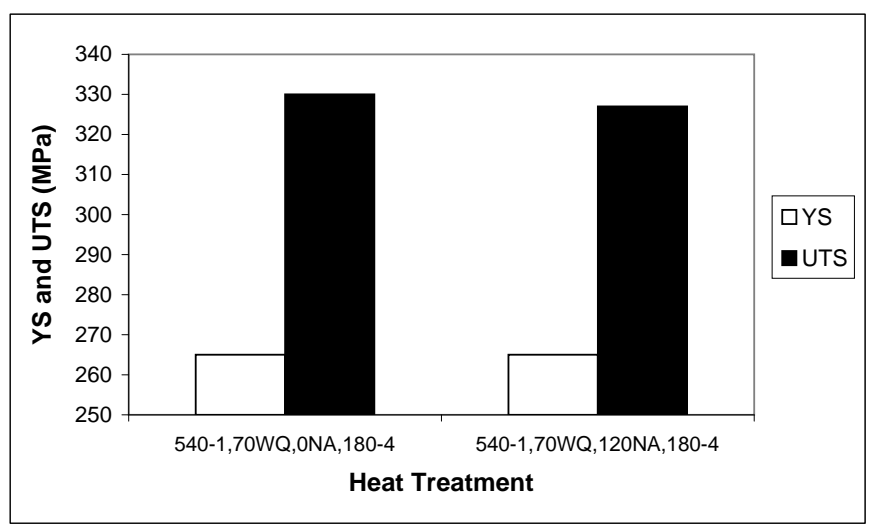

Fig. (24). Tensile properties for samples artificially aged at $180^{\circ} \mathrm{C}$ for $4 \mathrm{~h}$ after different natural aging periods $(0.40 \mathrm{wt} \% \mathrm{Mg})$. Samples quenched in $70^{\circ} \mathrm{C}$ water.

- Maximum hardness is reached after only 1 hour at $180^{\circ} \mathrm{C}$ with no prior natural aging. This time increases to 4 hours in all naturally aged samples.

- $\quad$ The tensile properties of A356-T4 and A356-T6 are not influenced significantly by shortening the solution treatment from 6 hours to 1 hour.

- $\quad$ The impact properties of A356-T4 and A356-T6 are slightly improved by using a shorter solution treatment of only 1 hour, rather than 6 hours.

- $\quad$ The impact strength of SSM HPDC A356-T4 is significantly higher than that of SSM HPDC A356-T6.

- Linear relationships were found between wt\% $\mathrm{Mg}$ of alloy A356 (within specification) and yield strength, ultimate tensile strength and impact strength for both the T4 and T6 tempers.

- Quenching in water at $70^{\circ} \mathrm{C}$ after solution treatment results in slightly lower tensile properties (T4 and T6) than quenching in water at $25^{\circ} \mathrm{C}$.

- $\quad$ The higher water quench temperature after solution treatment leads to a more sluggish artificial aging response.

- $\quad$ The effects of any natural aging can largely be removed by an artificial aging treatment of $180^{\circ} \mathrm{C}$ for 4 
hours, regardless of the water quench temperature after solution treatment.

\section{ACKNOWLEDGEMENTS}

The contributions of L. Ivanchev, D. Wilkins, G. Kunene (SSM HPDC) and C. McDuling, F. Blum and A. Grobler (tensile testing) are gratefully acknowledged.

\section{REFERENCES}

[1] Flemings MC, Martinez RA. Principles of microstructural formation in semi-solid metal processing. Solid State Phenom 2006; 116117: $1-8$.

[2] Lashkari O, Ghomashchi R. The implication of rheology in semisolid metal processes: An overview. J Mater Process Technol 2007; 182: $229-40$.

[3] Liu D, Atkinson HV, Kapranos P, Jirattiticharoean W, Jones H. Microstructural evolution and tensile mechanical properties of thixoformed high performance aluminium alloys. Mater Sci Eng A 2003; 361: 213-224.

[4] Dewhirst BA. Optimization of the heat treatment of semi solid processed A356 aluminum alloy. Masters Thesis, Worcester Polytechnic Institute, 2005.

[5] Rosso M, Actis Grande M. Optimization of heat treatment cycles for automotive parts produced by rheocasting process. Solid State Phenom 2006; 116-117: 505-8.

[6] Möller H, Govender G, Stumpf WE. The T6 heat treatment of Semi-solid Metal Processed Alloy A356. Open Mater Sci J 2008; 2: 6-10.
[7] ASM Specialty Handbook: Aluminium and Aluminium Alloys. ASM International, Materials Park: Ohio; 1993.

[8] Ivanchev L, Wilkins D, Govender G. Proceedings of the $8^{\text {th }}$ international conference on semi-solid processing of alloys and composites; Limassol, Cyprus; 2004.

[9] Kaufmann H, Fragner W, Galovsky U, Uggowitzer PJ. Proceedings of the $2^{\text {nd }}$ International light metals technology conference; St. Wolfgang, Austria: 169-177.

[10] Emadi D, Whiting V, Sahoo M, Sokolowski JH, Burke P, Hart M Optimal heat treatment of A356.2 alloy. Light Met 2003: 983-9.

[11] Gupta AK, Lloyd DJ, Court SA. Precipitation hardening processes in an $\mathrm{Al}-0.4 \% \mathrm{Mg}-1.3 \% \mathrm{Si}-0.25 \% \mathrm{Fe}$ aluminium alloy. Mater Sci Eng A 2001; 301: 140-6.

[12] Zhang DL, Zheng LH, StJohn DH. Effect of short solution treatment time on microstructure and mechanical properties of modified Al-7wt\%Si-0.3wt\%Mg alloy. J Light Met 2002; 2: 27-36.

[13] Ogris E. Development of Al-Si-Mg alloys for semi-solid processing and silicon spheroidization treatment for Al-Si cast alloys. Doctorate dissertation, Swiss Federal Institute of Technology, Zurich, 2002.

[14] Möller H, Govender G, Stumpf WE. The natural and artificial aging response of semi-solid metal processed alloy A356. Submitted to: $10^{\text {th }}$ International Conference on Semi-Solid Processing of Alloys and Composites. Aachen, Germany; September 2008.

[15] Möller H, Govender G, Stumpf WE. The natural and artificial aging response of the semi-solid metal processed Al-Si-Mg alloy A356. Int J Cast Met Res; 2008.

[16] Möller H, Govender G, Stumpf WE. Improvement of the T6 heat treatment of rheocast Alloy A356. J New Generation Sci; 2008. 